\title{
EVALUASI PURNA HUNI MASJID ULIL ALBAB KAMPUS 2 UMS
}

\author{
Abdul Rochim H., Alpha Febela Priyatmono \\ Program Studi Teknik Arsitektur, Fakultas Teknik, Universitas Muhammadiyah Surakarta \\ Jl. A. Yani Tromol Pos 1 Pabelan Kartasura Sukoharjo 57102 Telp 0271-717417 \\ Email : generalmanager_007@yahoo.co.id
}

\begin{abstract}
ABSTRAK
Masjid merupakan tempat sujud atau tempat menyembah Allah SWT. Kenyamanan beribadah di dalam masjid memerlukan pengaplikasian aspek teknik, fungsi, dan perilaku yang tepat agar tercipta sebuah perencanaan desain yang nyaman bagi penggunanya. Tujuan penelitian ini adalah membahas bagaimana aspek teknik, fungsi, maupun perilaku yang ditemukan pada Masjid Ulil Albab Kampus 2 Universitas Muhammadiyah Surakarta dengan melakukan pendekatan observasi, analisa dan penarikan kesimpulan. Metode evaluasi purna huni digunakan untuk mengetahui tingkat keberhasilan sebuah desain bangunan baik dalam aspek kenyamanan maupun keterkaitannya dengan lingkungan sekitarnya. Dalam proses evaluasi ini terdapat beberapa metode-metode yang bisa di pakai untuk memecahkan masalah-masalah yang timbul (problem seeking) serta menemukan pemecahan masalahnya (problem solving). Hasil penelitian ini menunjukkan adanya penyimpangan aspek teknik, fungsi, maupun perilaku yang perlu ditinjau ulang agar tercipta sebuah desain masjid yang memenuhi aspek kenyamanan maupun keterkaitan dengan lingkungan.
\end{abstract}

\section{Kata Kunci: evaluasi purna huni, masjid, (aspek teknik, fungsi, perilaku)}

\section{PENDAHULUAN}

Masjid berasal dari bahasa arab sajada yang berarti tempat sujud atau tempat menyembah Allah SWT. Bumi yang kita tempati ini adalah masjid bagi kaum muslimin. Setiap muslim boleh melakukan shalat di wilayah manapun di bumi ini, kecuali diatas kuburan, di tempat yang bernajis, dan di tempat yang menurut ukuran syariat Islam tidak sesuai untuk dijadikan tempat shalat (Fanani, 2009).

Masjid tidak bisa dilepaskan dari masalah shalat, berdasarkan sabda Nabi Muhammad SAW setiap orang bisa melakukan shalat dimana saja dirumah, di kebun, di jalan, di kendaraan, dan tempat lainnya. Selain itu masjid merupakan tempat orang berkumpul dan melaksanakan shalat secara berjamah, dengan meningkatkan solidaritas dan silaturahmi di kalangan kaum muslimin. Di masjid pula tempat terbaik untuk melangsungkan shalat Jum'at.

Salah satu masjid di lingkungan Universitas Muhammadiyah Surakarta adalah Masjid Ulil Albab yang berlokasi di kampus 2 . Setiap waktu sholat tiba masjid penuh dengan jamaah sholat fardhlu, apalagi ketika sholat jum'at dilaksanakan, di masjid ini akan tumpah ruah sampai ke pelataran masjid, teras perpustakaan dan teras gedung ekonomi. Masjid ini terlalu kecil untuk ukuran masjid kampus yang memiliki banyak pengguna, apalagi masjid ini berada di lingkungan universitas yang menyandang organisasi islam.

Pada awal masjid dibangun dengan ukuran $12 \mathrm{~m}$ x $12 \mathrm{~m}$ termasuk teras sudah penuh setiap terlaksananya sholat jamaah sehingga dalam pelaksanaan sholat harus antri. Untuk menambah daya tampung jamaah sholat fardhu pihak takmir sudah melakukan perluasan tempat sholat yang juga berguna sebagai serambi dengan ukuran $12 \mathrm{~m} \times 13 \mathrm{~m}$. Walau sudah diperluas tempat sholat tetap saja saat sholat jum'at tumpah ruah karena memang jamaah dari mahasiswa dan staff universitas yang banyak, akan tetapi saat sholat fardhu harian sudah bisa menampung jamaah.

Serambi yang pada awalnya untuk perluasan tempat sholat berubah fungsi menjadi tempat jamaah sholat, pada saat yang sama sebelum maupun setelah sholat 
ada jamaah yang sekedar istirahat maupun bercerita dengan teman, sehingga terkadang membuat ramai dan mengganggu jamaah yang sedang sholat di area serambi tersebut.

Penelitian ini adalah sebagai tanggapan dari banyak jamaah yang menyatakan bahwa kondisi mendengar maupun ketika shalat berjamaah di Masjid Ulil Albab ini tidak begitu jelas / khusyuk. Hal ini disebabkan karena terjadinya suara dari luar dan tidak ada pembatas dengan lingkungan luar, maka desain ruangan masjid perlu di pertimbangkan. Tujuan Penelitian ini mendiskusikan tentang cara meningkatkan pemanfaatan serambi masjid sebagai ruang sholat maupun ruang diskusi yang nyaman.

\section{TINJAUAN PUSTAKA \\ Evaluasi Puma Huni}

Evaluasi Purna Huni merupakan cara atau metode untuk mengetahui tingkat keberhasilan sebuah desain bangunan baik dalam aspek kenyamanan maupun keterkaitannya dengan lingkungan sekitarnya, dalam proses evaluasi ini terdapat beberapa metode-metode yang bisa di pakai untuk mencari masalah-masalah yang timbul (problem seeking) serta menemukan pemecahan masalahnya (problem solving). (Rahmawati, 2005)

\section{Aspek Fungsional}

Aspek fungsional adalah aspek yang penekanannya pada faktor kegunaan yang dapat menunjang prestasi (kerja, kuliah), melalui metode wawancara, observasi, angket/questioner, walk-trough interview.

(Rahmawati, 2004).

\section{Aspek Teknis.}

Aspek teknis merupakan aspek yang penekanannya terhadap kesesuaian dengan standar, melalui metode pengukuran, observasi, kearsipan, angket/questioner.( Rahmawati, 2004) Dalam melakukan evaluasi ini kami menggunakan peralatan antara lain: meteran (untuk mengetahui luas masjid dan besaran ruangannya), foto / kamera digital (untuk mengetahui tampilan fisik bangunan).

\section{Aspek Perilaku}

Faktor fungsional yang ada dan perilaku yang nampak akan dapat dilihat suatu indikasi apakah bangunan ini sudah berfungsi sebagaimana mestinya dan apakah para penggunanya merasa nyaman. Elemen perilaku, yaitu aspek - aspek yang berkait dengan psikologi, sosiologi dan kepuasan penghuni bangunan (Rahmawati, 2004)

\section{Masjid \\ Pengertian Masjid}

Masjid berasal dari bahasa arab sajada yang berarti tempat sujud atau tempat menyembah Allah SWT. Dalam pengertian bahasa itu, seluruh muka bumi adalah masjid; Artinya orang yang mendirikan shalat dimana saja di muka bumi dinyatakan sah shalatnya, kecuali di beberapa tempat yang ditetapkan agama terlarang seperti kuburan dan toilet. Akan tetapi di samping pengertian semantik, masjid juga mempunyai pengertian 'syarak'. Dalam pengertian ini masjid adalah sebuah bangunan, tempat ibadah umat Islam, yang digunakan umat terutama sebagai tempat dilangsungkannya shalat jama'ah.

\section{Jenis - Jenis Masjid}

Menurut wujudnya masjid dibedakan menjadi :

a) Masjid jami' merupakan tempat yang dipersiapkan selamanya untuk sholat dan kemudian dikhususkan lagi baik yang dibangun dengan menggunakan batu, tanah, semen ataupun yang belum dibangun dan dilaksanakan sholat jumat dan sholat fardhu.

b) Mushola merupakan tempat yang dipersiapkan tidak selalu untuk sholat. Seorang bisa sholat di sana jika tiba-tiba ia mendapatkan waktu sholat. Tempat ini tidak disebut dengan masjid dan tempat sholat biasanya ukurannya lebih kecil daripada masjid jami' dan tidak digunakan untuk sholat jum'at, akan tetapi untuk melaksanakan sholat fardhu harian.

\section{Fungsi Masjid}

Sebagai Baitullah masjid adalah tempat turunnya rahmat Allah SWT dan malaikat Allah, karena itu, masjid dalam pandangan Islam merupakan tempat yang paling baik di muka bumi. Di masjid kaum muslimin menemukan ketenangan hidup dan kesucian jiwa, di sana terdapat majelis-majelis dan forum terhormat. Masjid bagi umat merupakan institusi yang paling penting untuk membina suatu masyarakat muslim. 
Masjid merupakan tempat untuk menumbuhkan rasa kesatuan dan persatuan umat Islam. Di masjid semua strata masyarakat bertemu, dalam derajat yang sama, karena Allah SWT tidak memandang strata masyarakat; Dihadapan Allah SWT. yang paling terhormat adalah yang paling bertakwa. Dalam bidang keagamaan, masjid berfungsi sebagai tempat melakukan sholat yang dalam hadits disebutkan sebagai tiang agama, baik fardhu maupun sunah. Masjid juga berfungsi sosial, dan berfungsi sebagai tempat pendidikan, terutama pendidikan keagamaan, pengajian, dan kegiatan-kegiatan sosial lainnya.

Masjid di zaman Islam, juga merupakan institusi politik dan pemerintahan, karena di masjidlah dilangsungkannya musyawarah politik, latihan militer, dan administrasi negara.

\section{METODE PENELITIAN Identifikasi}

Identifikasi ini mencoba untuk menemukan hal-hal yang menjadi faktor penentu bagi keberlangsungan bangunan dan dampaknya pada pengguna bangunan. Juga menemukan suatu dampak utama dan permasalahan yang timbul dari penghuni setelah sekian lama memakai bangunan tersebut.

\section{Investigasi}

Investigasi yang dilakukan, pertama dengan melakukan survei langsung di Masjid Ulil Albab Universitas Muhammadiyah Surakata dengan kuisioner yang memuat pertanyaan pertanyaan yang dikembangkan dari identifikasi yang telah ada. Investigasi meliputi:

1. Elemen-elemen teknis, yaitu hal-hal yang berkait dengan permasalahan teknis desain, seperti halnya, kesehatan, keamanan, sanitasi, daya tahan bangunan dan lainnya.

2. Elemen-elemen fungsional, yaitu hal-hal yang berkait dengan pengoperasian yang berdampak pada efisiensi dan efektifitas.

3. Elemen perilaku, yaitu aspek - aspek yang berkait dengan psikologi, sosiologi dan kepuasan penghuni bangunan

\section{Diagnosa}

Diagnosa yang dilakukan dengan memberikan pertimbangan-pertimbangan desain sesuai dengan temuan-temuan investigasi, yaitu survei dan kuisioner, kemudian melakukan analisis lebih mendalam. Analisis yang dilakukan dengan mempertirnbangkan perbaikan disain dan sisi fungsi, efisiensi, efektifitas, persepsi penghuni, dan kenyamanan.

\section{Tujuan dan Manfaat Penelitian. \\ Tujuan Penelitian}

a) Mengevaluasi Masjid Ulil Albab Kampus 2 UMS Surakarta dari segi fungsi, teknik dan perilaku.

b) Mendapatkan rekomendasi atau keluaran perencanaan dan perancangan untuk Masjid Ulil Albab Kampus 2 UMS selanjutnya.

\section{Manfaat Penelitian.}

a) Memahami keadaan Masjid Ulil Albab Kampus 2 UMS dari segi fungsi, teknik dan perilaku.

b) Memberikan referensi, masukan, rekomendasi kepada institusi mengenai perencanaan dan perancangan Masjid Ulil Albab Kampus 2 UMS.

\section{Obyek Penelitian}

Obyek penelitian adalah masjid Ulil Albab di Kampus 2 Universitas Muhammadiyah Surakarta.

Denah masjid terbagi atas empat ruang yaitu mihrab, ruang sholat, serambi dan tempat wudhu.

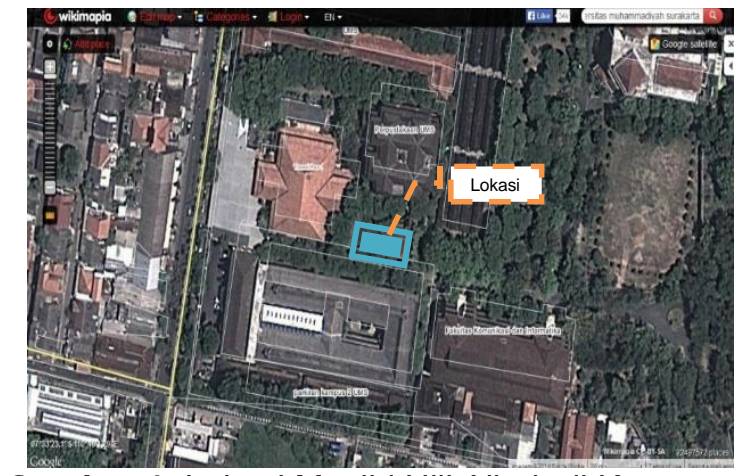

Gambar 1. Lokasi Masjid Ulil Albab di Kampus 2 UMS

Sumber: www.wikimapia.com 


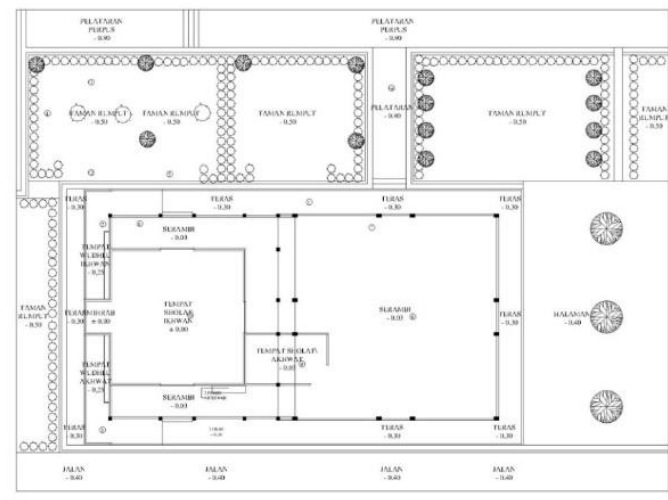

Gambar 2. Denah Masjid Ulil Albab Sumber: Survei lapangan, 2013

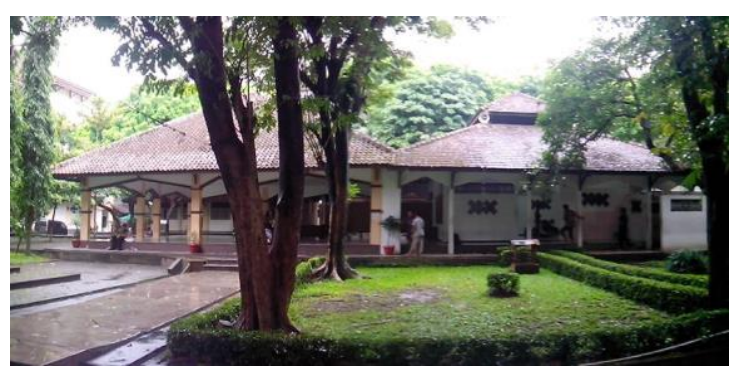

Gambar 3. Tampak masjid Ulil Albab Sumber: Survei Lapangan, 2013

Masjid Ulil Albab UMS memiliki luas $27 \mathrm{~m} \times 15,5 \mathrm{~m}$ dengan pembagian ruang utama masjid $(8 \mathrm{~m} \times 8 \mathrm{~m})$ yang dapat menampung jamaah sholat \pm 100 orang dan serambi masjid $(15 \mathrm{~m} \times 12 \mathrm{~m})$ dapat menampung jamaah sholat \pm 350 orang. Masjid ini dilengkapi dengan 2 tempat wudhu yang terletak di sebelah Utara (untuk putra) dan Selatan (untuk putri).

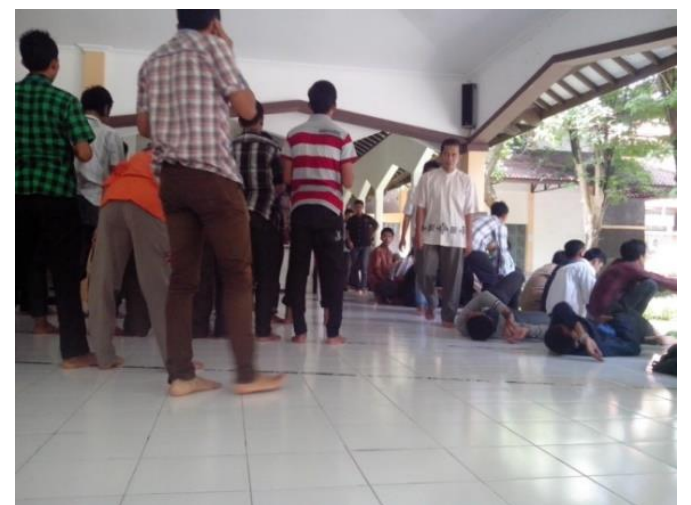

Gambar 4. Salah satu dampak sholat di serambi Sumber: Survei Lapangan, 2013

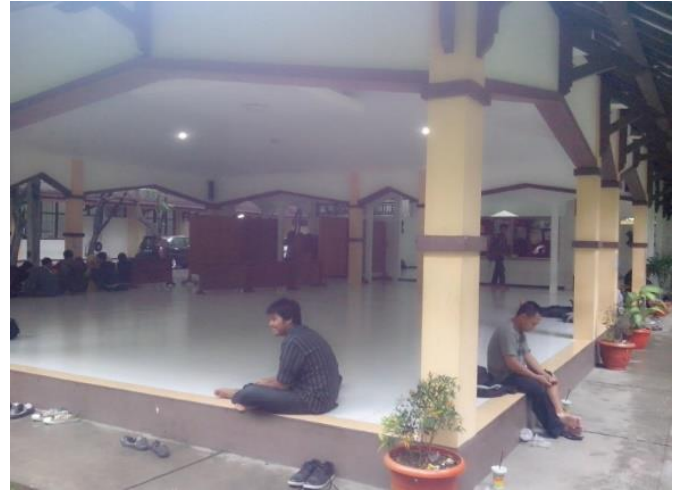

Gambar 5. Kondisi serambi masjid Ulil Albab Sumber: Survei Lapangan, 2013

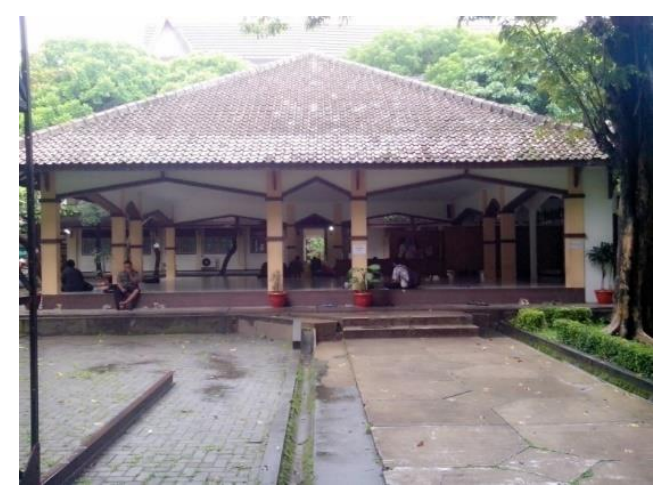

Gambar 6. Kondisi serambi masjid Ulil Albab Sumber: Survei Lapangan, 2013

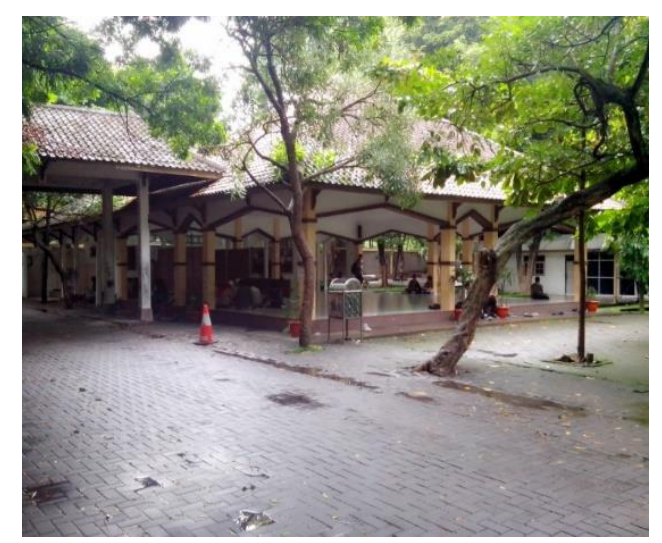

Gambar 7. Kondisi serambi masjid Ulil Albab Sumber: Survei Lapangan, 2013

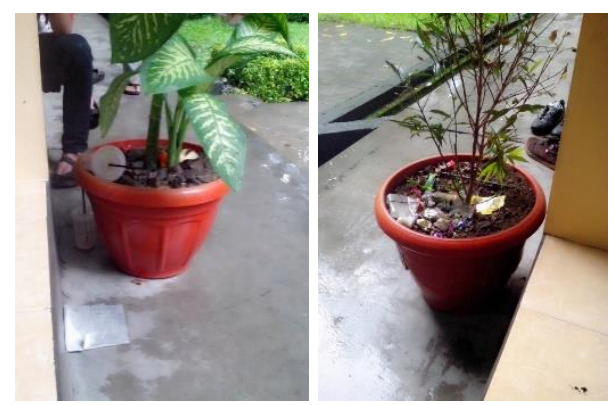

Gambar 8. Kondisi kebersihan serambi masjid ulil albab

Sumber: Survei Lapangan, 2013 


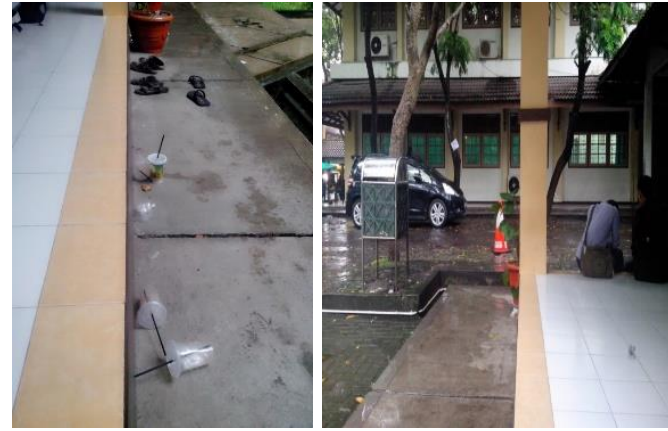

Gambar 9. Kondisi kebersihan serambi masjid Ulil Albab

Sumber: Survei Lapangan, 2013

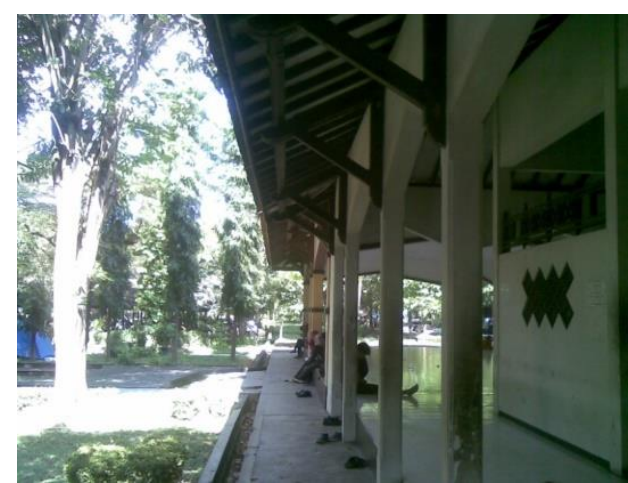

Gambar 10. Kondisi tritisan atap serambi masjid Ulil Albab

Sumber: Survei Lapangan, 2013

\section{Aktifitas Pengguna}

Beberapa aktifitas yang dilakukan oleh jama'ah Masjid Ulil Albab Kampus 2 Surakarta adalah sholat. membaca alquran, kajian, diskusi, istirahat, online, menunggu waktu sholat, istirahat, mengerjakan tugas.

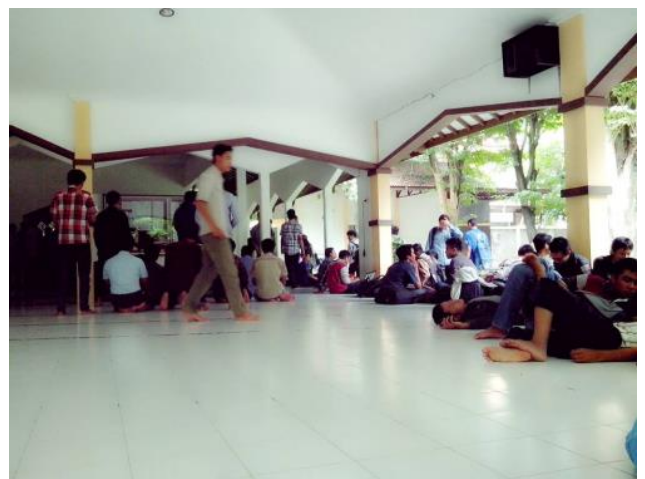

Gambar 11. Mahasiswa istirahat setelah melaksanakan sholat

Sumber: Survei Lapangan, 2013

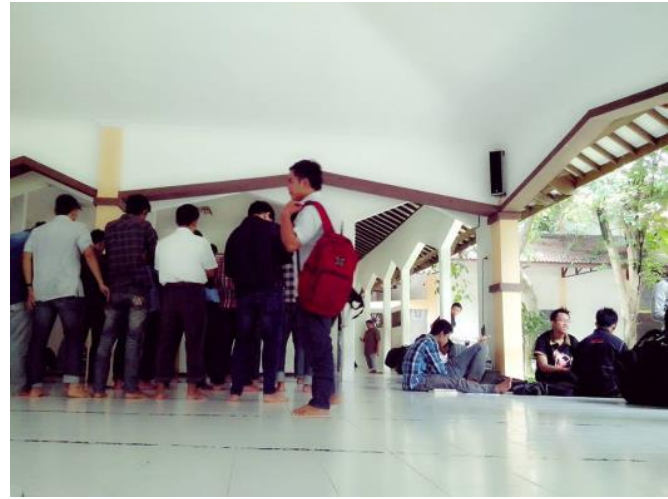

Gambar 12. Jama'ah melaksanakan Sholat dhuhur berjama'ah

Sumber: Survei Lapangan, 2013

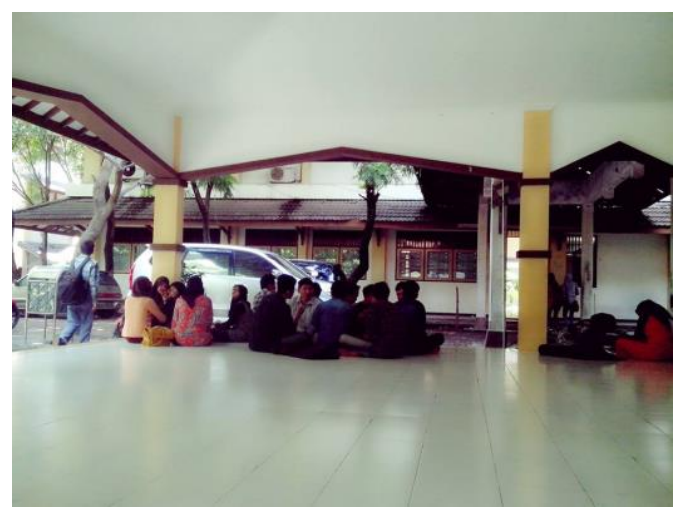

Gambar 13. Mahasiswa sedang berdiskusi bersama teman-temannya

Sumber: Survei Lapangan, 2013

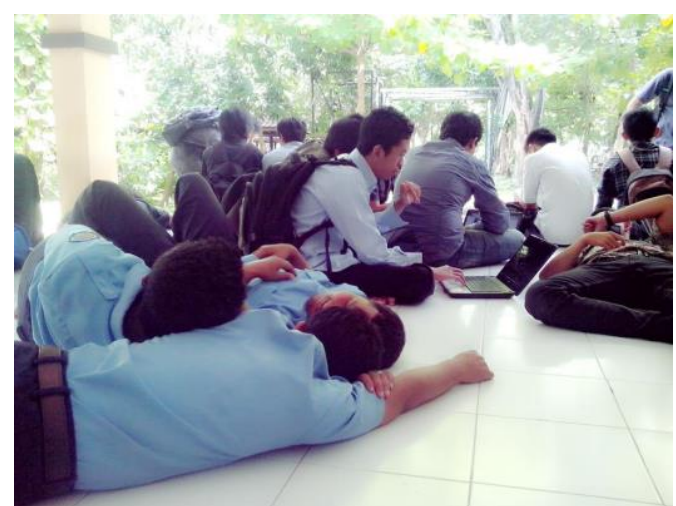

Gambar 14. Beberapa orang yang beristirahat di serambi masjid

Sumber: Survei Lapangan, 2013 


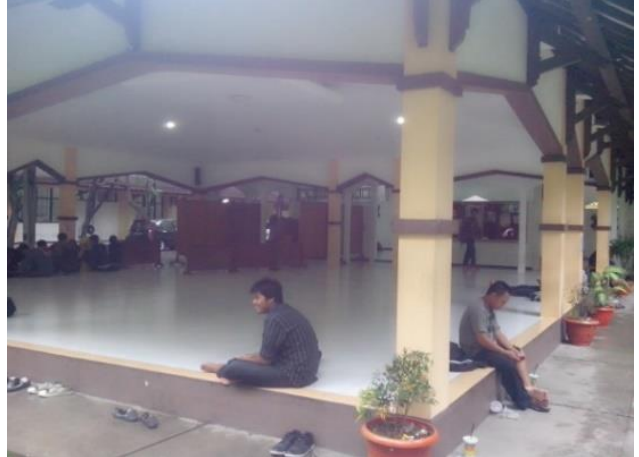

Gambar 15. Beberapa orang menunggu waktu sholat

Sumber: Survei Lapangan, 2013

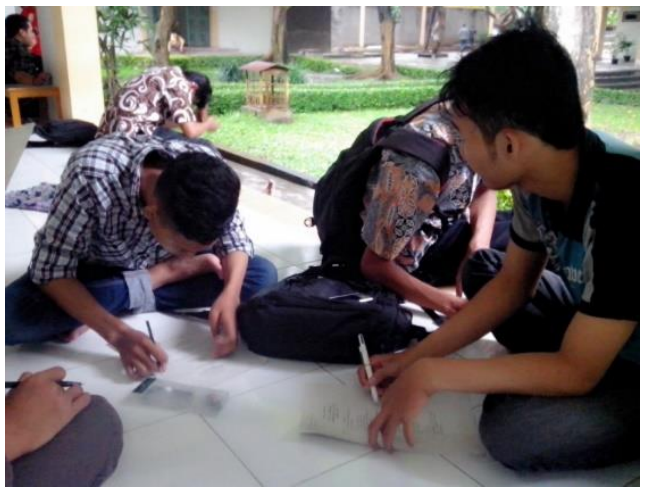

Gambar 16. Beberapa orang sedang mengerjakan tugas

Sumber: Survei Lapangan, 2013

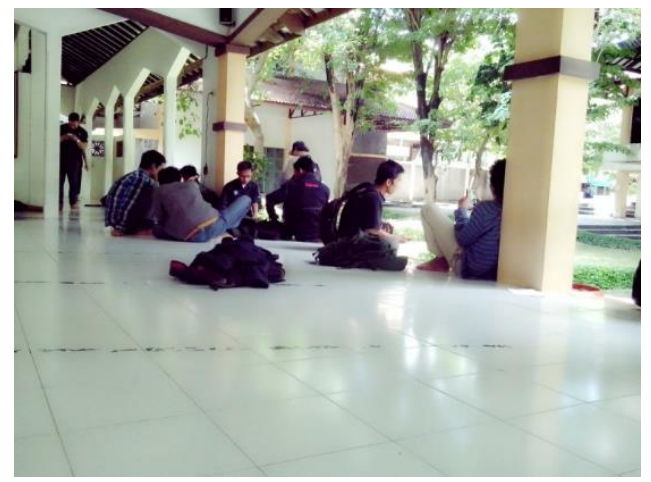

Gambar 17. Beberapa orang sedang berbincang-bincang

Sumber: Survei Lapangan, 2013

\section{Hasil dan Pembahasan \\ Hasil Quisioner}

Untuk mengetahui aspek teknis, fungsional, dan perilaku pengguna serambi masjid Ulil Albab Kampus 2 dilakukan investigasi dengan menyebarkan questioner kepada 10\% (34 orang) dari pengguna serambi. dengan perbandingan staff dengan mahasiswa 25\% : 75\%. Adapun pertanyaan yang harus dijawab oleh responden adalah sebagai berikut :
1. Cukup seringkah Anda melakukan sholat di serambi masjid ini?

A : Lebih dari 3 kali dalam seminggu

$B$ : Kurang dari 3 kali dalam seminggu

C : Hanya sesekali dalam seminggu

2. Sudah cukupkah ruang sholat untuk berjamaah sholat fardlu?

A: Ruang sholat mampu menampung jama'ah dalam sekali imam.

B: Ruang sholat mampu menampung jama'ah dalam dua kali imam.

C: Ruang sholat mampu menampung jama'ah namun dalam tiga atau lebih imam.

3. Apa yang anda rasakan saat sholat di serambi (kondisi suara lingkungan)?
A : Suara hening
B : Suara terdengar samar
C : Suara berisik

4. Menurut anda bagaimana kekhusyu'an sholat di Serambi?
A : khusyu'
B : Kurang khusyu
C : Tidak khusyu'

5. Mengganggukah orang yang tidak sedang melaksanakan sholat ketika Anda sholat di serambi?
A : Tidak Mengganggu
B : Cukup Mengganggu
$\mathrm{C}$ : Mengganggu

6. Menurut Anda bagaimanakah tempat wudlunya?

A : Bersih, air lancar, cukup menampung jama'ah yang ingin berwudhu

B : Cukup bersih, air cukup lancar, cukup menampung jama'ah yang ingin berwudhu

C : Kotor, Air macet, tidak cukup menampung jama'ah yang ingin berwudhu.

7. Menurut anda bagaimana kondisi kebersihan serambi masjid?
A : Bersih
B : Kurang Bersih
C : Kotor

8. Bagaimanakah keamanan di Serambi Masjid?
A : Aman, ada loker tempat penitipan barang
B : Kurang aman, ada tempat penitipan barang
C: Kurang Aman, Tidak ada tempat penitipan barang. 
9. Menurut anda, bagaimanakah fungsi serambi?
A : Serambi digunakan sebagai tempat istirahat, tempat melakukan kegiatan lain selain sholat.
B : Serambi hanya di gunakan untuk sholat.
C : Serambi tidak di gunakan untuk kegiatan apapun.

10. Perlukah partisi penyekat untuk yang sedang melaksanakan sholat diserambi?
A : Perlu
B : Kurang perlu
C : Tidak perlu

11. Sudah cukupkah sarana dan prasarana di Masjid?
A : Sudah cukup
B : Kurang cukup
C : Tidak cukup

12. Aktifitas lain yang sering anda lakukan selain shalat di serambi masjid?
A : Membaca Al-Qur'an, kajian, ber- diskusi
B : Kajian, berdiskusi
C : Ngobrol, menunggu teman yang sedang sholat

13. Perlukah serambi masjid di renovasi?
A : Perlu
B : Kurang perlu
C : tidak perlu

Dari penyebaran kuesioner didapatkan hasil seperti di bawah ini:

Tabel 1. Hasil Penyebaran Kuesioner

\begin{tabular}{|c|l|c|c|c|}
\hline No & \multicolumn{2}{|c|}{ Pertanyaan } & \multicolumn{3}{|c|}{ Jawaban } \\
\cline { 2 - 5 } & \multicolumn{1}{|c|}{ A } & B & C \\
\hline 1 & $\begin{array}{l}\text { Cukup seringkah Anda } \\
\text { melakukan sholat di } \\
\text { serambi masjid ini? }\end{array}$ & 19 & 11 & 4 \\
\hline 2 & $\begin{array}{l}\text { Sudah cukupkah ruang } \\
\text { sholat untuk berjamaah } \\
\text { sholat fardlu? }\end{array}$ & 9 & 10 & 15 \\
\hline 3 & $\begin{array}{l}\text { Apa yang anda rasakan } \\
\text { saat sholat di serambi } \\
\text { kondisi suara lingkungan) }\end{array}$ & 1 & 15 & 18 \\
\hline 4 & $\begin{array}{l}\text { Menurut anda bagaimana } \\
\text { kekhusyu'an sholat di } \\
\text { serambi? }\end{array}$ & 6 & 26 & 2 \\
\hline 5. & $\begin{array}{l}\text { Mengganggukah orang } \\
\text { yang tidak sedang melak- } \\
\text { sanakan sholat ketika } \\
\text { anda sholat di serambi? }\end{array}$ & 6 & 20 & 8 \\
\hline 6 & $\begin{array}{l}\text { Menurut Anda } \\
\text { bagaimanakah tempat } \\
\text { wudlunya? }\end{array}$ & 6 & 25 & 3 \\
\hline 7 & $\begin{array}{l}\text { Menurut anda bagaimana } \\
\text { nnyyyy}\end{array}$ & 14 & 18 & 2 \\
\hline
\end{tabular}

\begin{tabular}{|c|l|c|c|c|}
\hline & $\begin{array}{l}\text { kondisi kebersihan } \\
\text { serambi masjid? }\end{array}$ & & & \\
\hline 8 & $\begin{array}{l}\text { Bagaimanakah keamanan } \\
\text { di serambi Masjid? }\end{array}$ & 5 & 6 & 23 \\
\hline 9 & $\begin{array}{l}\text { Menurut anda, bagai- } \\
\text { manakah fungsi serambi? }\end{array}$ & 27 & 7 & - \\
\hline 10 & $\begin{array}{l}\text { Perlukah partisi penyekat } \\
\text { untuk yang sedang } \\
\text { melaksanakan sholat } \\
\text { diserambi? }\end{array}$ & 28 & 4 & 2 \\
\hline 11 & $\begin{array}{l}\text { Sudah cukupkah sarana } \\
\text { dan prasarana di Masjid? }\end{array}$ & 12 & 20 & 2 \\
\hline 12 & $\begin{array}{l}\text { Aktifitas lain yang sering } \\
\text { anda lakukan selain shalat } \\
\text { di Serambi Masjid? }\end{array}$ & 8 & 11 & 15 \\
\hline 13 & $\begin{array}{l}\text { Perlukah serambi masjid di } \\
\text { renovasi? }\end{array}$ & 28 & 4 & 2 \\
\hline
\end{tabular}

Sumber : Hasil Kuisioner, 2013

Berdasarkan tabel diatas maka didapatkan hasil seperti di bawah ini :

1. $56 \%$ cukup sering melakukan sholat di serambi masjid ini

2. $44 \%$ menyatakan ruang sholat tidak cukup untuk berjamaah sholat fardlu dalam $3 \times$ imam.

3. $53 \%$ merasakan saat sholat di serambi (kondisi suara lingkungan) suara berisik.

4. $76 \%$ menyatakan kurang khusyu' sholat di serambi.

5. 59\% menyatakan cukup mengganggu orang yang tidak sedang melaksanakan ketika anda sholat di serambi.

6. $74 \%$ menyatakan tempat wudlunya cukup bersih, air cukup lancar, cukup menampung jama'ah yang ingin berwudhu.

7. $53 \%$ menyatakan kondisi kebersihan serambi masjid kurang bersih.

8. $68 \%$ menyatakan keamanan di serambi masjid kurang aman.

9. $79 \%$ menyatakan fungsi serambi digunakan sebagai tempat istirahat, tempat melakukan kegiatan lain selain sholat.

10. $82 \%$ menyatakan perlu partisi penyekat untuk yang sedang melaksanakan sholat diserambi.

11. $59 \%$ menyatakan kurang cukup sarana dan prasarana di Masjid.

12. $44 \%$ menyatakan aktifitas lain yang sering dilakukan selain shalat di serambi masjid adalah ngobrol, menunggu teman yang sedang sholat.

13. $82 \%$ menyatakan perlu Serambi masjid di renovasi. 
Dari sisi kuisioner menunjukkan bahwa diperlukan adanya renovasi agar dalam beribadah tidak terganggu. Dengan sedikit tambahan partisi sebagai batas antara yang sholat dengan yang tidak sholat supaya tidak mengganggu orang yang sedang melaksanakan sholat.

Ditinjau dengan metode Evaluasi Purna Huni dari segi teknis dan permasalahan fungsional dan perilaku. Masalah yang timbul yaitu:

1. Secara keseluruhan Serambi Masjid belum memenuhi aspek teknis, fungsi, dan perilaku sesuai dengan perencanaan.

2. Adapun bagian dari serambi masjid yang menyimpang dari perencanaan:

- Teknis:

- Tidak ada sekat antara yang sedang sholat dan yang sedang istirahat.

- Sekat sholat antara jamaah ikhwan dengan akhwat yang tidak terlalu tinggi.

- Tidak adanya talang yang menyebabkan air hujan tempias ke lantai serambi.

- Fungsi:

- Fungsi serambi yang universal harus ada pembatas antara fungsi yang satu dengan yang lain.
- Perilaku:

- Tingkat kesadaran pengguna untuk membuang sampah pada tempat yang sudah disediakan.

- Kurang peduli terhadap yang sedang sholat di serambi.

\section{Kesimpulan}

Serambi masjid secara umum sudah sesuai pemanfaatannya sebagai perluasan tempat sholat jika di tempat sholat utama tidak mencukupi. Namun terdapat permasalahan, baik yang berhubungan dengan teknis, fisik, maupun perilaku. Ada permasalahan yang timbul antara lain suara berisik yang ditambah oleh orang-orang yang tidak sedang sholat sehingga mengganggu orang yang sedang sholat.

\section{Saran Rekomendasi Pendekatan Desain}

a) Pemberian sekat untuk pembatas antara yang sedang sholat dan yang sedang istirahat dengan partisi yang dapat dipindah sebagai pembatas yang bisa dipindah jika tika diperlukan dan tidak banyak memakan tempat.

b) Pemberian talang di sepanjang ujung atap agar air tidak langsung turun dan jatuh tempias ke lantai.

\section{DAFTAR PUSTAKA}

Amrulloh, Hafidz, 2012. Perancangan Masjid Ekologis di Kota Surakarta. Tugas Akhir, Fakultas Teknik, Program Studi Teknik Arsitektur, Universitas Muhammadiyah Surakarta : Surakarta.

Huda, Syaiful, 2013. Redesain Pondok Pesantren Darul Ihsan Muhammadiyah Sragen dengan Pendekatan Sistem Hijab. Tugas Akhir, Fakultas Teknik, Program Studi Teknik Arsitektur, Universitas Muhammadiyah Surakarta : Surakarta.

Fanani, Achmad, Arsitektur Masjid, Bentang, Yogyakarta, 2009

Mastuhu, Dinamika Sistem Pendidikan Pesantren, Jakarta, 1994

Nawawi, Ramli, Kongres Budaya Banjar, Surakarta, 2007

Qaradhawi, Yusuf, Fiqih Wanita, Jabal-Bandung, Februari 2007

Sukino, Ahmad, Materi Pengajian Ahad Pagi Yayasan Majelis Tafsir Alqur'an (MTA), Surakarta, Maret 2009

Peraturan Daerah Kota Surakarta No 8 Tahun 2009 tentang Bangunan 
SNI 03-1733-2004 tentang Tata Cara Perencanaan Lingkungan Perumahan di Perkotaan http://eprints.uny.ac.id/9018/3/bab\%202\%20-08404244044.pdf

http://id.wikipedia.org/wiki/Masjid\#Aturan_dan_etika 